First Peoples Child \& Family Review

A Journal on Innovation and Best Practices in Aboriginal Child Welfare Administration,

Research, Policy \& Practice

\title{
Incidence of Maltreatment of Aboriginal Children Reported to Youth Protection in Quebec: Intercultural Comparisons
}

\section{Marc Tourigny, Pascale Domond, Nico Trocmé, Bruno Sioui and Karine Baril}

Volume 3, Number 3, 2007

URI: https://id.erudit.org/iderudit/1069400ar

DOI: https://doi.org/10.7202/1069400ar

See table of contents

Publisher(s)

First Nations Child and Family Caring Society of Canada

ISSN

1708-489X (print)

2293-6610 (digital)

Explore this journal

Cite this article

Tourigny, M., Domond, P., Trocmé, N., Sioui, B. \& Baril, K. (2007). Incidence of Maltreatment of Aboriginal Children Reported to Youth Protection in Quebec: Intercultural Comparisons. First Peoples Child \& Family Review, 3(3), 103-119. https://doi.org/10.7202/1069400ar
Article abstract

The purpose of the study is to examine reported cases of maltreatment in Aboriginal children and compare them with cases involving non-Aboriginal children based on a sample of such cases reported to Youth Protection services in Quebec. Results indicate that, in Quebec, cases involving Aboriginal children compared with cases for non-Aboriginal children are characterized by living situations such as subsidized housing, substance abuse in parents, an increased number of children in the family, the fact that a case reported was a 'social emergency'and that a case was less reported by the mother. Intervention plans with Aboriginal families and suggestions for future research are discussed.
Copyright @ (c Marc Tourigny, Pascale Domond, Nico Trocmé, Bruno Sioui, Karine Baril, 2007
This document is protected by copyright law. Use of the services of Érudit (including reproduction) is subject to its terms and conditions, which can be viewed online.

https://apropos.erudit.org/en/users/policy-on-use 


\title{
Incidence of Maltreatment of Aboriginal Children Reported to Youth Protection in Quebec: Intercultural Comparisons*
}

\author{
Marc Tourigny $^{\mathrm{a}}$, Pascale Domond ${ }^{\mathrm{b}}$, Nico Trocméc, Bruno Sioui ${ }^{\mathrm{a}}$, et Karine Baril ${ }^{\mathrm{a}}$
}

a Département de psychoéducation de l'Université de Sherbrooke. ${ }^{\text {b}}$ Département de psychologie de I'UQAM

c School of Social Work, McGill University, Montreal

\section{Introduction}

The issue of child maltreatment in Aboriginal communities $^{1}$ has been the object of numerous debates for a number of years and is a major concern for youth protection services in Canada and in the province of Quebec. Throughout Canada (with the exception of Quebec), Blackstock, Trocmé and Bennett (2004) compared data on the maltreatment of Canadian Aboriginal children with data on Canadian non-Aboriginal children and with non-Aboriginal children from other ethnic communities. The results of the comparative study provided knowledge on the incidence of maltreatment for two groups and revealed significant differences as to the types of maltreatment, the context in which they emerged and the related consequences. The differences indicate the importance of taking into account intercultural divergences in the study of child maltreatment in Canada.

The comparative approach is positive in terms of increased knowledge, prevention and treatment as it fosters the organizational development of intervention services and programs adapted to the specific needs

Acknowledgment: We wish to thank all professionals at DYP (Director of Youth Protection) services for their valuable contribution to the project. Requests for copies may be sent to Marc Tourigny, Département de psychoéducation, Faculté d'éducation, Université de Sherbrooke, 2500, boul. de l'Université, Sherbrooke (Québec), Canada, J1K 2R1. (E-mail: Marc.Tourigny@USherbrooke.ca)

\begin{abstract}
The purpose of the study is to examine reported cases of maltreatment in Aboriginal children and compare them with cases involving non-Aboriginal children based on a sample of such cases reported to Youth Protection services in Quebec. Results indicate that, in Quebec, cases involving Aboriginal children compared with cases for non-Aboriginal children are characterized by living situations such as subsidized housing, substance abuse in parents, an increased number of children in the family, the fact that a case reported was a 'social emergency' and that a case was less reported by the mother. Intervention plans with Aboriginal families and suggestions for future research are discussed.
\end{abstract}

of Aboriginal and non-Aboriginal families. However, there is no information available to date on the various intercultural differences regarding maltreatment in Aboriginal and non-Aboriginal children in Quebec. The purpose of the study is to fill the gap in information by exploring the differences and similarities between Aboriginal and non-Aboriginal cases of maltreatment reported to Youth Protection services in Quebec.

\section{Aboriginal Population of Quebec}

According to the Indian Act, an Indian is "a person who is registered or entitled to be registered in the Indian Register" of the Department of Indian Affairs and Northern Development (DIAND), distinguishing between registered Indians, non-registered Indians and the Inuit (Native Affairs Secretariat, 2001). The diversified Aboriginal population of Quebec consists of 10 distinct Amerindian nations and one Inuit nation, living in approximately 60 communities throughout the province, and of which $70 \%$ live on reserve lands (Secrétariat aux affaires autochtones du Québec, 2001). In 2001, the Aboriginal Peoples Survey (APS) 
indicated that Quebec had an Aboriginal population of 79,400 persons or $8 \%$ of all Aboriginal peoples in Canada and $1 \%$ of the whole of the Quebec population (Statistics Canada, 2003). Of this number, in 2005, 68,735 were registered and 46,709 lived on-reserve (DIAND, 2006). According to the same survey, 34,090 children at the time were living within an Aboriginal family, approximately $2 \%$ of all children in Quebec. Sixty-eight percent $(68 \%)$ of the children were between 0 and 14 years of age, $1 \%$ more than observed for non-Aboriginal children within the same age group, $59 \%$.

From 1996 to 2001, the Aboriginal population grew at a greater rate than did the whole of the Quebec population, with an increase of $11 \%$, compared to $1 \%$ for Quebec in general. More recent 2005 reports indicate that the Aboriginal population of Quebec has again grown since 2001 (Secrétariat des affaires autochtones du Québec, 2005). Consisting of a population of 82,824 , the increase indicates that the number of Aboriginal children has also grown considerably since the last available information in 2001.

\section{History of Aboriginal Communities in Canada: Policies of Colonization and Assimilation}

Many historical accounts on Aboriginal peoples in Canada focus on the fact that in the 500 years following the arrival of Europeans, and more particularly in the course of the years following the adoption of the Indian Act of 1876, the result was that all Indians fell under the trusteeship of the Canadian government, which caused a social upheaval for Aboriginal peoples and disrupted their traditional values and way of life. In some instances, Aboriginal communities were completely annihilated by Canadian government policies and measures of assimilation ${ }^{2}$ (Royal Commission on Aboriginal Peoples, 1996; Dupuis, 2001). Their children were removed from the reserves and sent to residential schools; their form of government, their livelihood and traditions were regulated or banned under Canadian laws (Armitage, 1995; Bennett \& Blackstock, 2002; Fournier \& Crey, 1997; Réame \& Macklem, 1994). Other examples of racist and oppressive policies towards Aboriginal peoples outlined in reports include: the denied right to vote, regulated identity, banned right to purchase land, outlawed spiritual ceremonies, relocation onto reserves and imposed segregation, restricted civil and political rights, land expropriation under Canadian law (i.e. the Indian Act) and the forced removal of Aboriginal children to boarding schools where a high number of them, now 35 years of age or over, would have been physically and sexually abused (Commission de la santé et des services sociaux des Premières Nations du Québec et du Labrador, 2006).

\section{First Child Protection and Well-Being Systems Applied to Aboriginal Peoples}

Beginning in the early 1870 s, the Canadian government proceeded to set up residential schools for Aboriginal children between the ages of 5 and 16 in order to teach Aboriginal youth how to become productive members of society according to European and Christian beliefs (Miller, 1996). The children were removed from their homes and communities and placed in residential schools jointly run by the government and various religious communities. Aboriginal peoples were thus assimilated through the indoctrination of First Nations children into abandoning their way of life and their language. The schools were created by virtue of the Indian Act of 1876 and spread to all the provinces, particularly in western Canada and excluding the Maritime Provinces (Miller, 1996).

During the 1960s, Aboriginal youth were further the target of exploitation and maltreatment in institutions under the first youth protection and welfare systems, a health system for Aboriginal children in Canada (Armitage, 1995). Such systems did little to recognize the needs of Aboriginal communities and rather led to the disintegration of family and community life (Bennett \& Blackstock, 2002). One example of the inadequacy of youth protection and well-being policies for Aboriginal peoples points to living conditions and poverty, rather than maltreatment, as the main reasons for removing numerous Aboriginal children from their families. Although children were said to be institutionalized for reasons of serious abuse or negligence, living conditions or medical care were often the reason for intervention by youth protection agencies (Tiechroeb, 1997).

During the late 1960s in Canada, approximately $30 \%$ to $40 \%$ of children monitored by youth 
protection systems were Aboriginal children, although they represented less than $4 \%$ of the Canadian population (Fournier \& Crey, 1997). As of $1983^{3}$, the overrepresentation of Aboriginal children in youth protection systems had spread throughout Canada, notably with rates between $50 \%$ and $70 \%$ of First Nations children under guardianship in the Prairie Provinces (Armitage, 1995; Fournier \& Crey, 1997; Tiechroeb, 1997).

According to Tiechroeb (1997), only a small percentage of the children were returned to their families after having been placed in foster homes or adopted. As for the children who did return to their homesafterprolonged absences, they found themselves alienated from their family and cultural environments (Hudson \& McKenzie, 1985). Consequently, "Raised by middle-class, white parents, they grew up with little understanding or awareness of their roots" (Bennett \& Blackstock, 2002, p.22). The children also reported incidences of physical or sexual abuse by foster or adoptive parents (Tiechroeb, 1997).

\section{Impact of Social Policies on Aboriginal Peoples}

The relationship between the Federal government and the First Nations people, marked by social, economic, political and cultural pressure under assimilation policies, had a devastating effect on Aboriginal communities throughout Canada. Policies of colonization, expropriation and assimilation have had major repercussions particularly on the family unit with the breakdown of family ties, and their poor living conditions (Bennett \& Blackstock, 2002; Fournier \& Crey, 1997; Hudson, 1987; Kimelman, 1985). According to Bennett and Blackstock (2002), the forced implementation of provincial child welfare services under colonial policy and on Aboriginal communities has only exacerbated the devastating effects on First Nations people that endure to this day notably in terms of social and socio-economic problems including poverty, domestic violence, child maltreatment, criminal activity and substance abuse.

\section{Poverty}

Data provided in the 1991 report by the Canadian Council on Social Development indicate that Aboriginal peoples living in Canadian urban sectors were twice as likely to live in poverty than nonAboriginal peoples ${ }^{4}$ (Lochhead \& Shillington, 1996). In fact, while the average level of poverty for all urban inhabitants was $25 \%$, the level of poverty among Aboriginal peoples living in an urban area was 56\% for the same period. Similarly, the level of poverty among single-parent Canadian mothers was $45 \%$, whereas it reached $73 \%$ among Aboriginal mothers (National Council of Welfare, 2000). In addition, in $1995,60 \%$ of Aboriginal children six years of age or under lived within a poverty ridden family, compared to $25 \%$ for all Canadian children (National Council of Welfare, 2000). Living conditions observed in Aboriginal communities also had an impact on the average life expectancy of these children, which is eight years below the national average once they have reached adulthood (Fournier \& Crey, 1997). More recent data indicate that the issue of poverty among Aboriginal children continues to this day, as provided by the Canada census of 2001, with $40 \%$ of Aboriginal children outside the reserves living in poverty (Statistics Canada, 2003).

As for Quebec, data on the Aboriginal community in the 2001 Quebec census indicate that poverty exists among Aboriginal families in this province as well. For example, half of the Aboriginal population aged 15 years and over living in Quebec, or 25,880 persons, have an income of less than $\$ 15,330$ for the same period. There are little recent Quebec data available to indicate the level of poverty among Aboriginal peoples compared with non-Aboriginal peoples, however, data provided by the 1999 Canadian Council of National Development revealed that in 1995, 37\% of Aboriginal peoples were living beneath the low income level established by Statistics Canada, compared to $23 \%$ of all Québécois (Schetagne, 1999).

\section{Education, Employment and Unemployment}

The issue of employment and education among Aboriginal youth appears to be more of a hardship than among non-Aboriginal youth, with $14 \%$ of Amerindians, $17 \%$ of the Métis and $19 \%$ of the Inuit living off reserve and unemployed, compared to $8 \%$ for non-Aboriginal communities (Statistics Canada, 2003). Overall, Aboriginal youth 15 years of age and over present a much higher rate of unemployment than non-Aboriginal youth. As for the level of education, $19 \%$ of all Canadians 25 years of age and over 
have obtained a university degree (Bowlby, 2002), compared to only $8 \%$ of Aboriginal communities in Canada for the same age group (Kunz, Milan \& Schetagne, 2001; Statistics Canada, 2003).

In Quebec, according to Statistics Canada (2003), the level of Aboriginal university graduates in 2001 among persons aged 25 years or over was estimated at only $6 \%$ who obtained a university degree either at the undergraduate or graduate level (compared to $10 \%$ for the total population of Quebec); the level of Aboriginal youth who obtained an education below high-school level was estimated at $48 \%$ (compared to $39 \%$ for the entire Quebec population).

In terms of employment, in 2001, Aboriginal peoples represented 2\% of the working population of Quebec. However, the unemployment rate within this population was at $18 \%$ for the same period (MAINC, 2006).

To our knowledge, we have no data available to indicate that the issue of low education and employment has been resolved within the Aboriginal community of Quebec. Although there has been a clear improvement in the level of education among Aboriginal youth in the last three decades, the low level of education among Aboriginal communities reported in 2001 indicates that the issue affects more than half of Aboriginal youth and adults.

\section{Domestic Violence}

Aboriginal women are more at risk of being victims of domestic violence than are other Canadian women as a whole. The general social survey on spousal violence conducted in Quebec in 1999 revealed that $25 \%$ of Aboriginal women were abused by a spouse or ex-spouse in the course of the previous five years, compared to $8 \%$ for non-Aboriginal women (Jiwani, 2000). In addition, the probability of being killed by their spouse following separation was eight times higher among Aboriginal women than among non-Aboriginal women. Similarly, the most serious forms of abuse, those that are life threatening (being beaten, chocked, threatened with a firearm or sexually assaulted), were more prevalent among victimized Aboriginal women.

\section{Substance Abuse and Criminal Activity}

Alcohol consumption is a serious matter within Aboriginal communities. On the issue,
Bennett and Blackstock (2002, p.40) stated that the Royal Commission on Aboriginal Peoples (1996) concluded that "Of all addictive substances, alcohol poses the greatest threat to Aboriginal peoples and their communities" in Canada. An Ontario study that included data from 1985-86 quantified alcohol consumption by county, comparing counties with Aboriginal reserves and counties without Aboriginal reserves (Adrian, Payne, \& Williams, 1991). Counties that included reserves had a higher percentage of alcohol consumption than the other counties and the inclusion of reserves resulted in a $25 \%$ variation in alcohol abuse province wide. The study revealed a direct link between a low level of income and alcohol consumption; an additional $\$ 1000$ added to after tax benefits correlated with a .3 litre decrease in total alcohol consumption.

There are no specific data for Quebec on criminality within the Aboriginal communities; however, Canadian data indicate that it is a social problem. Results of the general social survey on domestic violence revealed that approximately $35 \%$ of the Aboriginal population in Canada had admitted to being victim of at least one crime within the 12 months preceding the study, compared to $26 \%$ for non-Aboriginal communities (Jiwani, 2000).

Aboriginal youth, compared with non-Aboriginal youth, have been involved in greater numbers in all aspects of the criminal justice system in Canada. Although they represented only $5 \%$ of the population in 2001-2002, they comprised more than $25 \%$ of admissions to sentenced custody, $22 \%$ of admissions to remand, $17 \%$ admissions to deferred custody and $16 \%$ of admissions to probation. The percentages vary from province to province (Government of Canada, 2005).

\section{Reported Incidents of Maltreatment in Ab- original Communities}

The Provincial/Territorial Ministry of Child and Family Services Annual Reports, 2000-2002 estimated that approximately 76,000 children were under protective services in Canada and that approximately $40 \%$ of these children were Aboriginal (FarrisManning \& Zandstra, 2003). As for the increase in Aboriginal people involved in youth protection services, the INAC (2006) indicates that the number of cases reported to youth protection in Aboriginal communities rose by 70\% between 1995 and 2003 . 


\section{Links Between Social Problems and the Mal- treatment of Children}

A number of studies indicate that maltreatment towards children, notably neglect, is largely associated with a child's socio-economic environment, characterized by the mother's low level of education, reduced socio-economic conditions, parental unemployment, parental substance abuse and domestic violence (Black, Heyman, \& Slep, 2001; Gelles \& Hargraves, 1990; O’Keefe, 1995; Schumacher, Slep, \& Heyman, 2001; Sedlak, 1997; Zuravin, 1987).

In spite of the correlation between the family's socio-economic condition and the incidence of child maltreatment, there are little data available on the issue for Aboriginal communities. In Quebec, there appears to be no data available on the link between child maltreatment and socio-economic risk factors, and as regards cultural specificity in cases of maltreatment reported to youth protection and involving an Aboriginal child.

\section{Comparison of Maltreatment in Aboriginal and non-Aboriginal Families}

There have been two Canadian cross-cultural studies conducted on maltreatment within Aboriginal and non-Aboriginal communities. In one exploratory study, Leung and Carter (1983) looked at cultural differences in maltreatment among Chinese, Native Indians, and Anglo-Canadian children based on files at the Vancouver General Hospital. Although the study was methodologically limited, it indicated that within Aboriginal families, foetal alcohol syndrome, neglect (in the form of "failure to thrive") and ecchymosis are more prevalent than within Anglo-Canadian families. As for the perpetrator of maltreatment, the study indicated that in Aboriginal families the mother was the prevalent perpetrator whereas in Anglo-Canadian families the perpetrator more often had no family tie with the child (for example mother's partner, babysitter and others).

Referring to a major Canadian study on child maltreatment, Blackstock et al. (2004) conducted a comparative analysis on cases reported to youth protection services in Canada involving Canadian Aboriginal and non-Aboriginal children (with the exception of Quebec) and non-Aboriginal children from other ethnic communities ${ }^{5}$. Findings indicated that, compared with the other two groups, a greater number of families of Aboriginal children: 1) lived on social welfare; 2) lived in unsafe housing; 3) had previously received the services of youth protection; 4) had issues of neglect; and 5) had moved during the previous six to 12 months.

As for the parents of Aboriginal children, compared with the other two groups, the differences were significant in terms of: 1) a history of maltreatment in their own childhood; 2) problems with substance abuse (drugs/alcohol) which are more prevalent; 3) a higher incidence of criminal activity; 4) a higher incidence of social isolation; 5) a higher incidence of mental illness or cognitive behaviour problems; and 6) the lowest age as parents. Finally, in the study, the fact of being an Aboriginal child indicated an increased likelihood that cases of maltreatment would be substantiated and that the child would be placed in out-of-home-care.

When compared with the other two groups, Aboriginal children mainly differed in terms of a higher incidence of substance abuse and school absenteeism.

\section{Limited Methodology}

In spite of the increased knowledge acquired through this type of comparative study, methodological limitations must be acknowledged. One limit pertains to the fact that the different findings between Aboriginal and non-Aboriginal communities could very well be due to economic and not cultural issues. As income level is a variable strongly associated with child maltreatment, and as Aboriginal families are distinctly economically disadvantaged, monitoring income level would better reveal culture associated differences. A second limitation concerns the use of univariate analyses to determine group differences. This type of approach does not allow for the unique role of each variable in identifying the characteristics of each group compared with the other. As such, multivariate methods of analysis would appear to be more favourable.

The present study aims to explore the incidence of maltreatment in Aboriginal children reported to youth protection services in Quebec based on a provincial sampling of such cases. More specifically, the study has two objectives: one, to describe reported cases involving Aboriginal children and two, to compare them with reported cases involving non-Aboriginal children. In order to offset the methodological 
limitations previously mentioned, both groups of children have been paired according to family income, the administrative region where the family lives and the caregivers in the child's life.

\section{Methodology}

\section{Procedure}

The study includes two subsidiary analyses conducted using data provided by a Quebec Incidence Study (Étude d'incidence québécoise - ÉIQ ${ }^{6}$ ) to document all cases reported and handled between October 1 and December 31, 1998. The cases come from 16 to 18 administrative regions in Quebec, each under the Director of Youth Protection (DYP) services. Two regions were excluded from the survey due to low numbers compared to the population of Quebec as a whole and to difficulty of access to their remote location: Nunavik, with a population of 8,000

inhabitants and the Cree Lands of James Bay, with a population of 9,000 inhabitants.

The number of cases retained and documented (number of responses) during the study was calculated by dividing the number of cases documented by the number of cases recorded by the DYP for the same period (Tourigny et al., 2002). For all cases recorded $(\mathrm{N}=4,929)$, the average number of questionnaires completed was $86 \%$ (from $64 \%$ to $99 \%$ according to DYP services).

The final sampling in the study was taken from cases retained. According to the (Ministère de la Santé et des Services Sociaux, 1988: 5), a case is defined as - Any situation involving a child 0-17 years of age, reported to the Quebec Director of Youth Protection by a person who has reason to believe that the security or development of that child is at risk of being compromised.

\section{Sampling}

\section{Table 1}

Characteristics under which reported cases of Aboriginal children were paired with reported cases of non-Aboriginal children $(\mathrm{N}=430) \mathrm{f}$

\begin{tabular}{|c|c|c|c|c|}
\hline Characteristics of the Situations & Total $\mathrm{N}=430 \%$ & $\begin{array}{c}\text { Aboriginal } \\
\text { Children } \\
\mathrm{N}=215 \%\end{array}$ & $\begin{array}{c}\text { Enfants } \\
\text { Non Autoch. } \\
\mathrm{N}=215 \%\end{array}$ & $\begin{array}{l}\text { Chi-square } \\
\text { (dl) }\end{array}$ \\
\hline \multicolumn{5}{|l|}{ Youth Centre $^{1}$} \\
\hline North Shore & 30.2 & 30.2 & 30.2 & \\
\hline Abitibi/Témiscamingue & 15.3 & 15.3 & 15.3 & \\
\hline Montréal/Batshaw & 17.2 & 17.2 & 17.2 & \\
\hline Other youth centres & 37.2 & 37.2 & 37.2 & \\
\hline Annual Family Income & & & & $13.25(5)$ \\
\hline Less than $\$ 15,000$ & 40.0 & 39.1 & 40.9 & \\
\hline$\$ 15,000$ to $\$ 24,999$ & 21.9 & 26.0 & 17.7 & \\
\hline$\$ 25,000$ to $\$ 40,999$ & 7.0 & 5.6 & 8.4 & \\
\hline$\$ 41,000$ and more & 3.0 & 2.3 & 3.7 & \\
\hline Living on social assistance & 15.8 & 17.7 & 14.0 & \\
\hline Unknown & 12.3 & 9.3 & 15.3 & \\
\hline \multicolumn{5}{|l|}{ Family Characteristics } \\
\hline Home life of the reported child & & & & $1.37(4)$ \\
\hline 2 birth parents & 42.3 & 42.6 & 42.5 & \\
\hline 1 birth parent with a partner & 19.7 & 18.6 & 20.9 & \\
\hline 1 birth parent alone & 31.0 & 31.2 & 30.8 & \\
\hline Other types of family life & 3.4 & 3.6 & 3.2 & \\
\hline Unknown & 3.6 & 4.5 & 2.7 & \\
\hline
\end{tabular}

(1) No statistical test was conducted for this variable as the pairing was precise. 
A first sampling was taken of 215 children whose cases were retained and who lived with at least one Aboriginal parent. For each child in the sampling, a comparable case of a non-Aboriginal child was also selected. The pairing was done based on the following characteristics: 1) the cases reported are from the same youth centre (Centre jeunesse); 2) the caregivers in the child's life; and 3) the annual family income. It was not possible to produce a perfect pairing because for a number of Aboriginal children, there was no nonAboriginal child with the exact same characteristics. However, Chi-squared tests indicate that the two groups were not significantly distinct under these three variables. The final sample therefore consisted of 215 pairs of children. Table 1 shows that the children in both groups were living predominantly with both biological parents $(42 \%)$ and almost one third of the children were living in a single-parent family (31\%). In the majority of cases, the family income was very low, with more than half (56\%) living in a family with an income of less than $\$ 15,000(40 \%)$ or on social assistance $(16 \%)$, and approximately one quarter (22\%) living in a family with an income between $\$ 15,000$ and $\$ 25,000$. In spite of slight differences between the two groups under this variable, there was no significant statistical difference. In terms of region, $30 \%$ of the children were from the North-Shore, $15 \%$ from the Abitibi-Témiscaminque region, $17 \%$ from the region of Montreal and 37\% from other regions of the province of Quebec.

\section{Variables}

The case-investigation form used to document retained cases was based mainly on measurement tools applied in similar studies such as the Ontario Incidence Study (Trocmé, McPhee, Tam, \& Hay, 1994), the National Incidence Study - NIS (Sedlak \& Broadhurst, 1996) and the Canadian Incidence Study - CIS (Trocmé et al., 2001). The form was completed at the end of the initial stage by a youth protection worker in charge at this step of the process. Information was collected on the characteristics of reported cases, substantiated cases of maltreatment, the child involved, adults with a parental role in the child's life, the child's living environment and child welfare services provided during the assessment stage.

\section{Characteristics of Retained Cases}

Questions focused on the description of retained cases such as the source of referral (10 separate sources

\begin{tabular}{|c|c|c|}
\hline Variables & $\begin{array}{l}\text { Canada } \\
\text { (Trocmé) }\end{array}$ & $\begin{array}{c}\text { Quebec } \\
\text { (Tourigny) }\end{array}$ \\
\hline $\begin{array}{l}\text { Family Structure* }^{*} \\
2 \text { biological parents } \\
\text { Reconstituted } \\
\text { Single-parent }\end{array}$ & $\begin{array}{l}21.9 \\
21.6 \\
56.5\end{array}$ & $\begin{array}{l}42.1 \\
18.6 \\
31.2\end{array}$ \\
\hline $\begin{array}{l}\text { Source of Income } \\
\text { Full Time } \\
\text { Part Time } \\
\text { Social Assistance* } \\
\text { Other }\end{array}$ & $\begin{array}{l}15.8 \\
10.2 \\
58.1 \\
16.0\end{array}$ & $\begin{array}{c}12.4 \\
7.2 \\
74.6 \\
5.7\end{array}$ \\
\hline Unsafe Housing & 7.9 & 10.5 \\
\hline $\begin{array}{l}\text { Move in the Past } 12 \text { Months } \\
\text { None } \\
1 \\
2 \text { or more }\end{array}$ & $\begin{array}{l}60.1 \\
22.9 \\
17.0\end{array}$ & $\begin{array}{l}68.8 \\
18.3 \\
12.9\end{array}$ \\
\hline $\begin{array}{l}\text { Characteristics of Maltreatment* } \\
\text { Unsubstantiated } \\
\text { Substantiated } \\
\text { Suspected } \\
\text { Physical Abuse } \\
\text { Sexual Abuse } \\
\text { Neglect } \\
\text { Emotional Abuse } \\
\text { Abandonment } \\
\text { Behaviour Problems } \\
\text { Domestic Violence }\end{array}$ & $\begin{array}{c}26.3 \\
49.5 \\
24.2 \\
18.6 \\
10.1 \\
57.9 \\
6.5 \\
\mathrm{Nd} \\
\mathrm{Nd} \\
7.0\end{array}$ & $\begin{array}{c}13.5 \\
80.9 \\
5.6 \\
14.9 \\
11.6 \\
62.3 \\
26.0 \\
7.4 \\
19.5 \\
\mathrm{Nd}\end{array}$ \\
\hline $\begin{array}{l}\text { Child Characteristics* }^{*} \\
\text { Substance Abuse and Birth } \\
\text { Anxiety or Depression } \\
\text { Number of Problems } 0 \\
\text { Number of Problems } 1 \\
\text { Number of Problems 2+ }\end{array}$ & $\begin{array}{c}6.1 \\
7.6 \\
77 \\
12.7 \\
10.3\end{array}$ & $\begin{array}{c}2.5 \\
7.4 \\
80.2 \\
11.9 \\
7.9\end{array}$ \\
\hline $\begin{array}{l}\text { Parent Characteristics* } \\
\text { Age: } \\
30 \\
31-40 \\
41-50 \\
51+ \\
\text { History of Maltreatment* } \\
\text { Alcohol and Drug Abuse* } \\
\text { Criminal Activity } \\
\text { Mental Health } \\
\text { Physical Health } \\
\text { Lack of Social Support }\end{array}$ & $\begin{array}{c}49.5 \\
44.7 \\
5.4 \\
0.4 \\
47.2 \\
91.0 \\
17.2 \\
21.7 \\
7.0 \\
33.9\end{array}$ & $\begin{array}{c}39.7 \\
43.1 \\
13.9 \\
3.3 \\
86.9 \\
53.2 \\
8.9 \\
15.8 \\
9.8 \\
29.4\end{array}$ \\
\hline
\end{tabular}

of referral), how cases were reported (regular services and social emergency), and the fact that the child was the object of a retained case within 12 months prior to the study or taken into custody within five years preceding the study.

\section{Substantiated Cases}

Seven forms of substantiated maltreatment (physical abuse, sexual abuse, neglect, abandonment, mental abuse, severe behaviour problems and others) were documented based on the written assessment by the 
youth protection worker. The definitions were provided through information collected on child welfare in relation to parental functioning - ICBE (Vézina \& Bradet, 1990), NIS (Sedlack, 1991), CIS (Trocmé et al., 2001) and through the Système clientèle jeunesse - SCJ (Trudeau \& Pellan, 1998) for serious behaviour problems.

\section{Characteristics of the Child, the Family and Caregivers}

The maltreatment investigation form provided information on child characteristics (age and sex) and eight forms of developmental problems (birth defects, developmental delay, hearing, sight or speech disability, chronichealthproblems, learningdisabilities, hyperactivity, psychiatric disorders, and depression/anxiety).

Family variables such as safe or unsafe housing conditions, home ownership or not, the number of reported children in the household, the presence of other primary caregivers (other than biological parents), the number of family moves within the previous 12 months and the number of siblings in the household were also measured.

Ten confirmed or suspected concerns (domestic violence, alcohol or drug abuse, criminal activity, mental health problems, physical health issues, lack of social support, cognitive impairment, history of abuse, custody dispute, financial issues/separation/divorce or other concerns) defined issues related to caregivers. For the present study, we used the total number of primary caregiver problems and issues seen as statistically significant between the two groups. The level of caregiver functioning was measured using the CIW four-point response scale ranging from "adequate" to "seriously inadequate" (Vézina \& Bradet, 1990) and the assessment form documented whether the caregiver had also been the victim of childhood abuse.

\section{Strategies of Analysis}

Chi-square tests and T-Tests were used to collect data on comparisons between Aboriginal and nonAboriginal children (SPSS Version 9 database). For the first objective, comparisons were based on 28 variables (Table 2). The 16 most significant variables were used in a linear logistic regression analysis in order to identify the variables between the two groups of children. When the variables are numerous and intercorrelated, the linear model diminishes the number of simultaneous variables, which results in more accurate estimates. As well, the comparison of results, step by
Table 2

Variables used in the univariate study for the two group comparison.

Characteristics of a Retained Case

1. Type of reporting*

2. Previous retained cases ( 12 mos) NS

3. Previous custody (5 years)*

4. Sources of referral - mother*

5. Sources of referral - extended family*

Variables Linked to a Substantial Case

6. Evidence of sexual abuse NS

7. Evidence of physical abuse NS

8. Evidence of neglect*

9. Evidence of abandonment NS

10. Evidence of psychological maltreatment NS

11. Evidence of behaviour problems*

12. Evidence of other problems NS

Variables Linked to the Reported Child and the Family

13. Sex of the child NS

14. Age of the child NS

15. Number of problems known in the child*

16. Number of services required for the child NS

17. Home life of the child NS

18. Number of children reported in the same family*

19. Number of children in the family*

20. Presence of another significant person NS

21. Number of moves NS

22. Type of work*

23. Unsafe housing*

24. Level of cooperation by parents*

25. History of maltreatment in a parent's childhood*

26. Number of known problems in the parent*

27. Evidence of a parent victim of domestic violence*

28. Evidence of parental alcohol and drug abuse*

${ }^{9}$ Nine other sources of referral were documented and tested statistically but no significant difference between the two was detected

step, provides some additional details on links between the variables. The order given to the three major categories of variables was; characteristics of cases reported, substantiated cases and characteristics of the reported child and family.

\section{Results}

\section{Univariate Analyses}

Results from Chi-squared tests revealed a number of major and significant differences between Aboriginal and non-Aboriginal reported cases (see Table 3).

\section{Characteristics of Retained Cases}

Results on the characteristics of retained cases indicate that cases involving Aboriginal children were more often handled by emergency services (26\% vs. $12 \%$ ) and that Aboriginal children had more frequently 


\section{First Peoples Child \& Family Review, Volume 3, Number 3, 2007}

Table 3

Characteristics of reported cases for Aboriginal and non-Aboriginal children and their families.

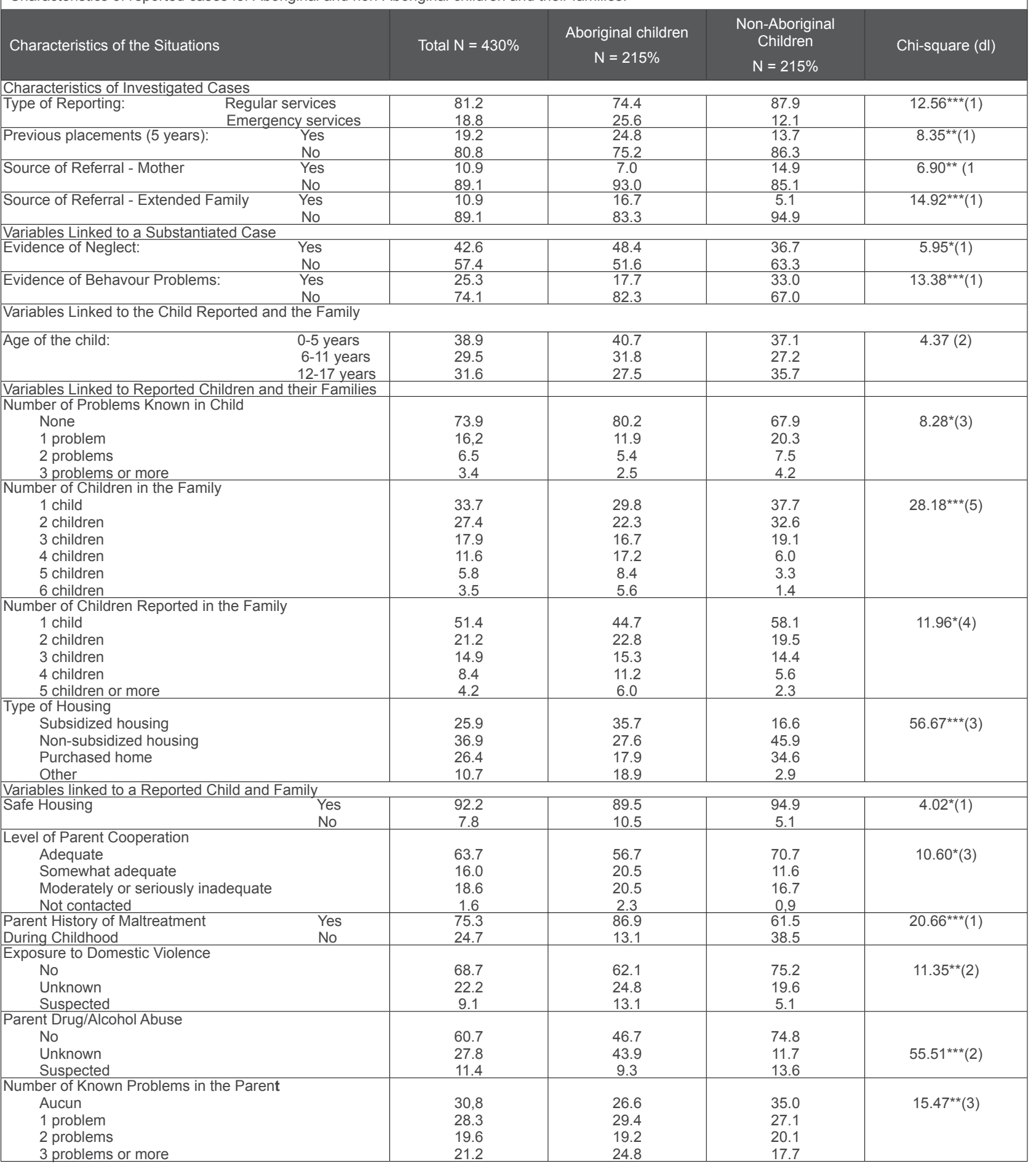

1. The odd-ratio is a measure of the increase of likelihood for one category compared to another. It identifies relative risk categories.

2. The odds-ratio confidence interval is a measure of the exactness of the estimated odds ratio.

3. The Wald test-statistic identifies categories where a phenomenon is the most frequent. However, if the likelihood is above 0.05 , the hypothesis that there is no difference between the two categories cannot be reached.

4. The likelihood estimator is an indicator of the parameters for each variable to predict the phenomenon, beyond the input of other variables included in the likelihood model. The likelihood takes into account the number of parameters used by a variable to predict the phenomenon.

(C) Marc Tourigny, Pascale Domond, Nico Trocmé, Bruno Sioui, et Karine Baril 
been taken into custody by child welfare agencies during the previous five years, compared with non-Aboriginal children ( $25 \%$ vs. $14 \%)$. Two major differences were noted as to the percentage of the various sources of referral: in cases involving Aboriginal children, fewer cases were reported by the mothers ( $7 \%$ vs. $15 \%)$ and were more often reported by a member of the extended family (17\% vs. $5 \%)$.

\section{Substantiated Cases}

Data provided on substantiated cases following an initial case evaluation revealed a higher number of children victims of neglect (48\% vs. $37 \%$ ) and a lower number of children with behaviour problems (18\% vs. $33 \%)$ within Aboriginal communities. The percentage of children victims of sexual, mental and physical abuse was similar in both groups.

\section{Characteristics of Children, Caregivers and Families in Reported Cases}

Data on the characteristics of reported children indicate that there is no distinction between Aboriginal and non-Aboriginal children in terms of the age of the child. However, Aboriginal children displayed fewer known problems than non-Aboriginal children. Finally, $80 \%$ of Aboriginal children displayed none of the problems listed in the study compared to $68 \%$ for non-Aboriginal children.

Aboriginal families had more children than nonAboriginal families with $48 \%$ of Aboriginal children living in a family of three or more children compared to $30 \%$ for non-Aboriginal children. In addition, $53 \%$ of Aboriginal children lived in a family with at least two reported children compared to $42 \%$ for nonAboriginal children. Finally, a higher percentage of Aboriginal children lived in subsidized housing (36\% vs. $17 \%$ ) and unsafe housing (11\% vs. $5 \%$ ) compared with non-Aboriginal children.

In terms of the caregivers, parent functioning was more often inadequate among Aboriginal parents than among non-Aboriginal parents (43\% vs. $29 \%$ ). Aboriginal parents were more often victims of maltreatment in their childhood (87\% vs. 62\%), more implicated in reported or suspected incidents of domestic violence (38\% vs. $25 \%$ ) and more implicated in reported or suspected substance abuse problems ( $53 \%$ vs. $25 \%$ ). In terms of known problems involving parents the situation was the same. Where three or more problems are identified among caregivers, Aboriginal parents are over-represented ( $25 \%$ vs. $18 \%$ ).

In order to determine which of the characteristics, distinguishing between Aboriginal and non-Aboriginal

Table 4

Factors associated with retained cases involving an Aboriginal child: Linear logistic regression model.

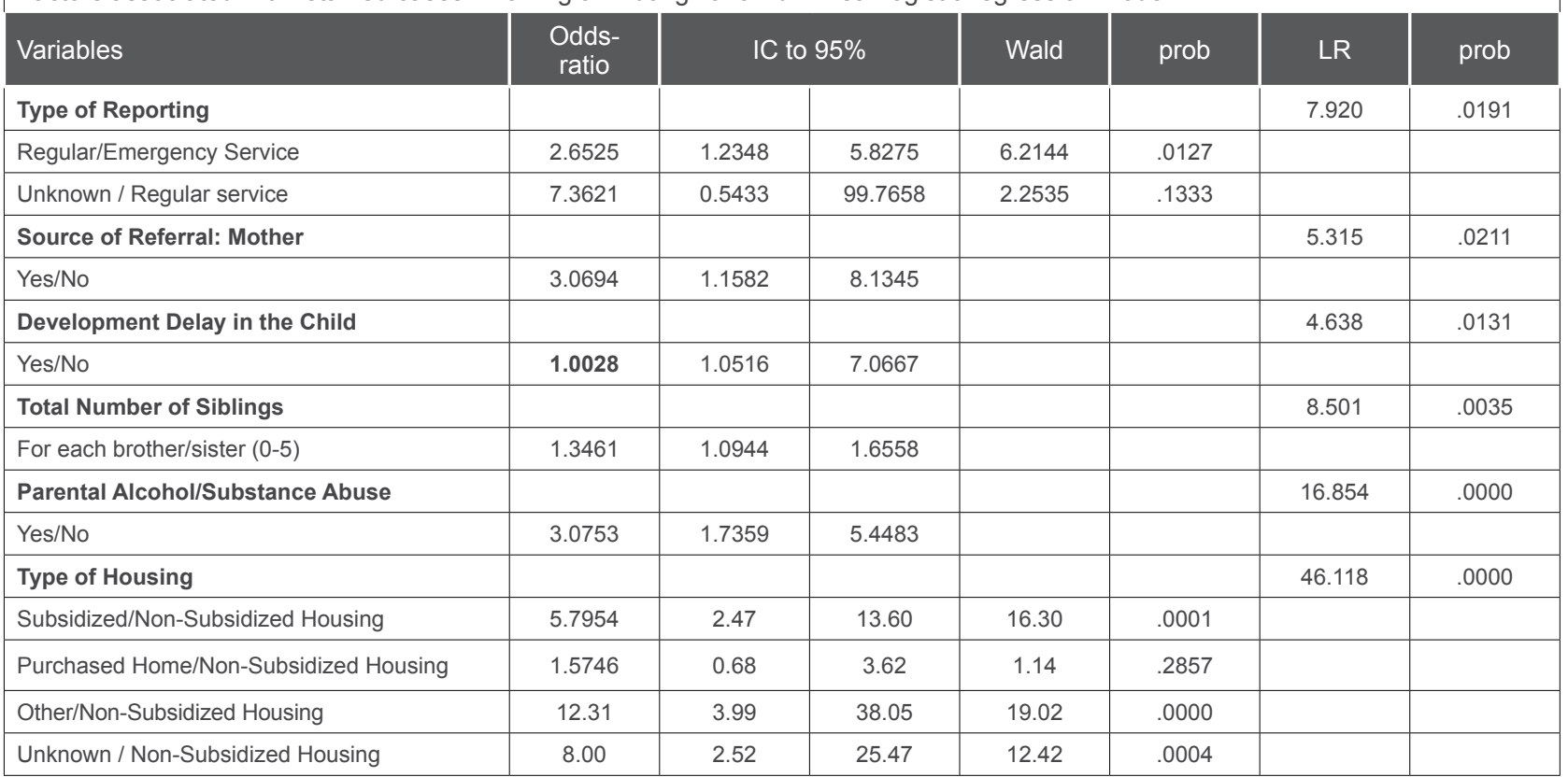


cases, make it possible to predict that a case reported to youth protection in Quebec is that of an Aboriginal child or a non-Aboriginal child, we conducted a logistic regression analysis on both groups of reported children.

\section{Multivariate Analyses}

Table 4 displays the results of a logistic regression model of factors associated with Aboriginal children reported to the Quebec Director Youth Protection. Results from the Hosmer and Lemeshow (1980) riskadjustment test indicate that there are no significant differences between the model predictions and the data noted (Goodness of Fit $=7.08 ; \mathrm{dl}=8 ; \mathrm{p}=.5278$ ), indicating that the model's estimates well reflect the data observed. In decreasing order of importance, the following factors reflect a higher probability that a case involves an Aboriginal child: 1) type of housing in that Aboriginal children more often live in a subsidized or other type of housing; 2) more reported or suspected parental substance abuse; 3) a higher number of children in the family; 4) the fact that a case was reported to emergency responders; 5) the fact that a case is less often reported by a mother; and 6) the fact that the children suffer less from developmental delay. The type of housing and known or suspected parental substance abuse are variables that are clearly most characteristic of a case involving an Aboriginal child.

The regression model obtained is an $81 \%$ accurate predictor for Aboriginal and non-Aboriginal reported cases. The model is a better predictor for non-Aboriginal cases $(86 \%)$ than for Aboriginal cases (76\%).

Some significant variables of the univariate analyses were not included in the regression model. The variables are: 1) previous custody (5 years); 2) the source of referral from the extended family; 3 ) variables linked to substantiated cases, such as neglect and behaviour problems; 4) the number of children reported within a family; 5) the level of parent functioning; 6) maltreatment of parents in their childhood; and 7) domestic violence.

\section{Discussion}

\section{Methodology - Strengths and Limitations}

The present study is the first to draw a provincial picture of cases of child maltreatment among Aboriginal children reported to the Director of Youth Protection (DYP) in Quebec. The study was based on a sampling of reported cases involving Aboriginal children within specific regions and for a defined period of time. The representation is not perfect as the short data collection period (Fall 1998) could have over-represented or underrepresented a number of seasonal phenomena ${ }^{7}$. In addition, two regions were excluded from the study, Nunavik and the Cree Lands of James Bay, two areas with a very high Aboriginal population. It should also be noted that the Quebec Incidence Study (ÉIQ - Étude d'incidence québécoise) includes only cases reported to youth protection agencies and as such does not provide an exact picture of issues of maltreatment involving Aboriginal children in Quebec.

A major limitation to this type of study comparing two ethnic groups is the bias linked to definitions used to identify maltreatment of children. Definitions used are more susceptible of reflecting the position of dominant ethnic groups in North America. It is quite possible that from the point of view of Aboriginal groups, the definitions do not exactly correspond to those within their culture. Major differences may be noted in terms of the definition of neglect and behaviour problems and to a lesser extent, in terms of the definition of physical and sexual abuse and particularly incest, which are more cross-culturally prevalent.

Some notable strong points of this type of study include the fact that both groups have been compared in terms of regions where cases were reported and family characteristics such as income, which help define cultural differences more accurately. Finally, using a multivariate analysis approach provided a more precise definition of the role for each variable included in the study.

\section{Poverty Among Aboriginal Families Report- ed to Youth Protection Services in Quebec}

Although indicators of poverty within Aboriginal families cannot explain the results of the comparative analyses, it is important to note that Aboriginal families in the study were a representative sampling of Aboriginal cases reported to youth protection services, while non-Aboriginals represented only a sub-group of their population within the group comparison. The percentage of Aboriginal families reported to youth protection and with an annual income of less than $\$ 15,000$ was $39 \%$ compared to $29 \%$ for all family cases reported to youth protection in Quebec, an indicator that poverty is a major issue in 
Aboriginal cases reported and a major characteristic of reported family cases. As such, finding solutions to the phenomenon of maltreatment within Aboriginal communities requires that the issue of poverty be taken into consideration.

\section{Characteristics of Reported Aboriginal Child Maltreatment Cases}

Results from the study indicate that in Quebec, characteristics surrounding child maltreatment cases differ very little between Aboriginal and non-Aboriginal children living in families with the same level of family income. Only six of the variables distinguish cases involving Aboriginal children, characterized by a higher proportion of: 1) cases reported to emergency responders; 2) families living in subsidized housing; 3) families with a higher number of children; and 4) parents with a substance abuse problem. Cases involving Aboriginal children also indicate a lower percentage of children with developmental delay and for which the source of referral was the mother.

\section{Crisis Situation}

A first major difference between the groups is that reported cases involving Aboriginal children are received twice as much as social emergencies than reported cases for non-Aboriginal children, in other words, outside regular service hours (8 a.m. to 5 p.m.). Cases reported may occur during a family crisis and come from the family's outer circle, including members of the extended family and individuals in the community, two sources that reported one quarter of all cases involving Aboriginal children.

\section{Family and Housing}

Reported Aboriginal families are characterized by a higher number of children in the family and by a lower number of families living in non-subsidized housing or in a purchased home. This overrepresentation also applies for the number of children per family within the Aboriginal community of Quebec compared with the population of Quebec as a whole (Indian and Northern Affairs Canada, 2002). The higher number of children can be a source of additional stressors for Aboriginal parents. It is also understood that there are fewer moves within Aboriginal families as a good number of them live on a reserve and therefore have a more stable living environment.

\section{Drug and Alcohol Abuse}

Cases involving parents of Aboriginal children more frequently include substance abuse problems, as also reported by Trocmé, Knoke and Blackstock (2004) in the CIS. Problems linked to alcohol and drug abuse are more prevalent in Aboriginal communities, as poverty is a major risk factor for substance abuse (Royal Commission on Aboriginal Peoples, 1996; Health Canada, 2006).

As well, parental alcohol and drug abuse is a risk factor for child maltreatment (Bays, 1990; Famularo, Kinscherff \& Fenton, 1992; Kelleher, Chaffin, Hollenberg \& Fischer, 1994; Peterson, Gable \& Saldana, 1996; Trocmé, McPhee \& Tam, 1995). Drug addiction in particular affects parent functioning by altering the capacity to assume a supervisory role (Dore, Doris \& Wright, 1995). In the Quebec Incidence Study, issues of mental abuse and neglect were most frequent in reported cases of parental alcohol and drug abuse. More specifically, the risk of neglect is 1.5 more prevalent in families with parental substance abuse than in families where substance abuse is not an issue (Wekerle, Wall, Leung \& Trocmé, 2004).

In the present study, although the issue of neglect is not identified in multivariate analyses as a variable that distinguishes the two groups, the number of children victims of neglect among Aboriginal children is higher than among non-Aboriginal children. Furthermore, compared with the sampling of children in the QIS, with $35 \%$ of all cases of child maltreatment reported in Quebec identified as victims of neglect, the number of Aboriginal children victims of some form of negligence is distinctly higher at $48 \%$. The prevalence of child neglect among Aboriginal families noted in previous studies could indicate a link with issues of parental substance abuse (Trocmé et al., 2004; McShane, 1988).

Within the context of child welfare services and Aboriginal families, it is important to work closely with parents with issues of alcohol and substance abuse. Although there are still no drug treatment programs that have clearly proven to be effective, Health Canada conducted a survey of programs put into place in Aboriginal communities. A number of programs were adapted for the needs of the Aboriginal culture and appear to show promising results.

\section{Developmental Delay and Behaviour Problems}

Results further indicate that Aboriginal children 
generally display fewer problems than non-Aboriginal children. The presence of developmental delay and behaviour problems appears to be more associated with non-Aboriginal children.

Considering the predominance of some family characteristics found in multivariate analyses, such as: 1) parental substance abuse; 2) parents with more than three problems; 3) exposure to domestic violence or; 4) parents with a history of childhood maltreatment, it is significant to note that Aboriginal children display fewer problems than do children in non-Aboriginal families. It is possible that Aboriginal children benefit more from the support of an extended family and as such are less affected by their parents' issues. A more stable lifestyle in terms of fewer moves among Aboriginal families might explain a support system not found among non-Aboriginal children. Results differ from those of Trocmé et al. (2004), who noted that Aboriginal children in Canada (excluding Quebec) had more problems than nonAboriginal children ${ }^{8}$. Significant differences noted were birth defects linked to substance abuse and childhood behaviour problems.

\section{Similarities and Differences Noted Between the QIS and the CIS}

Comparative data collected for the whole of Canada (except for Quebec) by Trocmé et al. (2004) on incidents of child maltreatment in Aboriginal and non-Aboriginal children reported to youth protection services are similar to comparative data obtained in Quebec, particularly as regards family characteristics. In both studies, the prevalence of substance abuse, the highest number of problems and a history of childhood maltreatment are reported more by Aboriginal than non-Aboriginal parents. As indicated earlier, there are differences noted between data collected from across Canada and in Quebec, particularly in terms of behaviour problems and known issues, the latter being more prevalent among Aboriginal than nonAboriginal children in the CIS and less reported for Aboriginal than non-Aboriginal children in the QIS.

Caution must be used in looking at comparative data for Canada and Quebec side by side. Individual results are difficult to compare for various reasons, notably as: 1) the Trocmé et al. (2004) study, unlike the Quebec study, did not pair the Aboriginal family sampling with family income; 2) the Canadian and Quebec samplings are different, Aboriginal families in the CIS appear to have increased social stressors (more one-parent families, more moves in the last 12 months, younger parents, more substance abuse, more criminal activity and more mental health problems among caregivers); 3) the Blackstock et al. (2004) studies include a third ethnic group, making it difficult to be absolutely precise in determining Aboriginal and non-Aboriginal differences; and 4) the definition of some variables such as behaviour problems differs from one study to the other. A number of tendencies can be noted in both studies without as such presenting exact comparisons.

\section{Challenges in Practice}

Considering that Aboriginal caregivers included in the study had multiple personal problems (financial problems, a history of maltreatment during their childhood, alcohol/drug abuse and domestic violence) and home life issues (high number of children and single parenthood) frequently associated with the risks of maltreatment (Schumacher et al., 2001), it is unrealistic to believe that issues of maltreatment and behaviour problems will cease without major forms of intervention being put into place to address these various factors.

Implementing treatment programs in Aboriginal communities must take into consideration their distinct cultural nature. According to Morin and Joncas (2004), there seems to be no contraindication to using, with Aboriginal children, a treatment program that has proven its worth among North American children. However, Morin and Joncas (2004), and many others, agree that even though treatment outcomes and practices may be transferable to the Aboriginal culture, tensions could arise and undermine treatment programs if nonAboriginal workers do not adopt culturally modified interpersonal skills to take into account Aboriginal values (LaDue, 1994; LaFramboise, Trimble, \& Mohatt, 1990; Health Canada, 2006; Solomon, Heisberger, \& Winer, 1981). An approach encouraging a more authoritative role by the participants than found in conventional forms of therapy appears to be more effective within Aboriginal communities (Heilbron \& Guttman, 2000). Others argue that traditional forms of family therapy, focused on the nuclear family, are inappropriate and need be adapted to include the extended family (Carter \& Parker, 1991; Heilbron \& Guttman, 2000), particularly when there is a clear collaborative effort for the treatment to be successful. Another issue to consider is the level of acculturation among reported Aboriginal families, their level of 
belief in traditional community values (Connors \& Oates, 1997; Topper, 1992). For Aboriginal people and their attachment to their traditional culture, elements of culture preference must be incorporated into treatment programs (Ashby, Gilchrist \& Miramontez, 1987; Heilbron \& Guttman, 2000). Consequently, it has been proposed to include community intervention in group therapy to provide moral support to the families in treatment (Heilbron \& Guttman, 2000). Recognizing links that exist among families and clans within the Aboriginal community can be very useful, notably to reduce sources of conflict that the families may encounter within their own community. The strong level of attachment to traditional values within various Aboriginal communities is a major consideration as non-Aboriginal professionals may otherwise find it increasingly difficult to offer their services (Darou, Kurtness \& Hum, 2000).

\section{Conclusion}

While the results of the present study may be useful for decision makers, professionals and researchers, they also raise questions that may be answered in future research projects. It appears necessary to acquire a deeperunderstanding of the phenomena of maltreatment and of behaviour problems among Aboriginal youth, by examining more closely and separately the characteristics of each issue, such as physical abuse, neglect, sexual abuse and psychological maltreatment. It would also be important to conduct a longitudinal study on Aboriginal and non-Aboriginal children for whom cases have been retained or substantiated by youth protection services in order to have a deeper knowledge of the path of these children and to better meet their needs and those of their families.

Moreover, it is essential to have abetterunderstanding of the definitions and forms of maltreatment as recognized by the Aboriginal community and determine the degree of convergence with those defined by the DYP. Motives and the context that compel members of the extended family to report issues of child maltreatment should also be documented.

\section{Endnotes}

1. The term Aboriginal designates the first people to have inhabited the country where they live. In the province of Quebec, Amerindians, persons of North American Indian descent and the Inuit are called Aboriginal (Secrétariat aux affaires autochtones du Québec, 2001). Aboriginal people in Quebec are distinct from the Québécois with European ancestry, born here but descendants of ancestors who began to emigrate here during the 17th century.

2. Policies of Aboriginal assimilation appear to have varied very little from on Canadian province to another, notably as pertains to Aboriginal affairs regulated by the Canadian government as of 1867 .

3. For this period, it is acknowledged that the total number of Aboriginal children placed in the care of non-Aboriginal people would possibly be higher than statistics indicate if non-status children and Métis children placed had been considered as Aboriginal children in the statistical data.." (Bennett \& Blackstock, 2002).

4. Aboriginal people who live on reserves and on the three territories, approximately $36 \%$ of the Aboriginal population, are not included in the data. As income is generally lower in the Aboriginal population living on reserves compared to the percentage that lives off reserve, including the above data would probably increase the issue of low income in Aboriginal children and adults.

5. The Canadian Incidence Study (CIS) was conducted using a representative sampling of cases reported to youth protection services in Canada over a three-month period, from October 1 to December 31, 1998 (Trocmé et al., 2001). The sampling used in the Blackstock et al. (2004) study does not include reported cases in the province of Quebec.

6. For more information on the methodology applied in the study, the reader may consult Tourigny et al. (2002).

7. See Tourigny et al. (2002) for more information on methodological strengths and limitations.

8. For the QIS, due to the specificity of the Child and Youth Protection Act (Loi sur la protection de la jeunesse - LPJ) a number of known problems in children as referred to by Trocmé et al. (2004) are outlined under the definition of behaviour problems (and not on the list of problems in children) in order to assess if the situation compromises the security or development of the child, as with other forms of maltreatment. The problems were not included under the variable "number of behaviour problems" as in the CIS. In spite of this difference, the results of the QIS reveal fewer behaviour problems in Aboriginal children, contrary to the $\mathrm{CIS}$ that reveals more behaviour problems in Aboriginal children than in non-Aboriginal children, pointing to a difference in findings between the two studies.

\section{References}

Adrian, M., Payne, N., \& Williams, R.T. (1991). Estimating the Effect of Native Indian Population on County Alcohol Consumption: The example of Ontario. Revue internationale sur la toxicomanie, $2,(5 \mathrm{~A}-6 \mathrm{~A}), 731-65$.

Affaires indiennes et du Nord canadien (2002). Données ministérielles de base - 2001. Ottawa: Ministère des Affaires indiennes et du Nord canadien.

Armitage, A. (1995). Comparing the Policy of Aboriginal Assimilation: Australia, Canada and New Zealand. Vancouver: University of British Columbia Press.

Ashby, M.R., Gilchrist, L.D., \& Miramontez, A. (1987). Group Treatment for Sexually Abused American Indian Adolescents. Social Work with Groups, 10, 21-32.

Bays, J. (1990). Substance Abuse and Child Abuse. Pedriatric Clinics of North America, 37, 881-904. 
Bennett, M., \& Blackstock, C. (2002). A Literature Review and Annotated Bibliography Focusing on Aspects of Aboriginal Child Welfare in Canada. Ottawa: First Nations of Child and Family Caring Society of Canada.

Black, D.A.,Heyman, R. E., \& Smith Slep,A. M. (2001). Risk Factors for Child Physical Abuse. Aggression and Violent Behavior, 6 (2-3), 203-229.

Blackstock, C., Trocmé, N., \& Bennett, M. (2004). Child Maltreatment Investigations Among Aboriginal and non-Aboriginal Families in Canada. Violence Against Women, 10 (8), 901-916.

Bowlby, J. (2002). Niveau d'études post-secondaires au Canada et aux États-Unis dans les années 90. Ressources humaines et développement Canada. $\mathrm{N}^{\circ}$ de cat. MP32-30/02-2F-IN Site internet: http://:www.hrsdc.gc.ca/fr/sm/ps/rhdc/rpc/publications/recherche/2002-000014/page01.shtml.

Carter, I., \& Parker, L.J. (1991). Intrafamilial Sexual Abuse in American Indian Families. In M.Q. Patton (Éd.), Family Sexual Abuse: Frontline Research and Evaluation (pp.106-117). Newbury Park, CA: Sage.

Commission royale sur les peuples autochtones (1996). Vers un ressourcement / Gathering Strength (Rapport final), 166p.

Commission de la santé et des services sociaux des Premières Nations du Québec et du Labrador (2006). Enquête régionale longitudinale sur la santé des Premières Nations de la région du Québec 2002: Rapport des Premières Nations vivant hors communauté en milieu urbain. Site: http://www.cssspnql.com:8080/cssspnq1/ui/strategy/document/erlspn final hors communaute fr.pdf.

Connors, E.A., \& Oates J.M.L.B. (1997). The Emergence of Sexual Abuse Treatment Models Within First Nations Communities. In D.A.Wolfe, R.J., McMahon, \& R.D. Peters (Éds.), Child Abuse: New Directions in Prevention and Treatment Across the Lifespan (p.223-247). Thousand Oaks, CA: Sage.

Conseil national du bien-être social. (2000). Profil de la pauvreté au Canada 1998, Ministère des ressources humaines et du développement social du Canada. Téléchargé à partir du site http://www. ncwcnbes.net/documents/researchpublications/ ResearchProjects/PovertyProfile/1998Report Fall2000/FRE/ReportFRE.htm.

Darou, W.G., Kurtness, J., \& Hum, A. (2000). The Impact of Conducting Research With a First Nation. Canadian Journal of Counseling / Revue Canadienne de Counseling, 34(1), 43-54.

Dore, M., Doris, J.M., \& Wright, P. (1995). Identifying Substance Abuse in Maltreating Families: A child welfare challenge. Child Abuse and Neglect, 19, 531- 543.

Dupuis, R. (2001). Quel Canada pour les Autochtones? Montréal : Boréal.

Famularo, R., Kinscherff, R., \& Fenton,T. (1992). Parental SubstanceAbuse and the Nature of Child Maltreatment. Child Abuse and Neglect, 16, 475-483.

Farris-Manning, C., \& Zandstra, M, (2003). Children in Care in Canada: A Summary of Current Issues and Trends with Recommendations for Future Research. Child Welfare League of Canada, Ottawa. Site internet: http://www.cecw-cepb.ca/DocsEng/ ChildrenInCareMar2003Final.pdf.

Fournier, S., \& Crey, E. (1997). Stolen from Our Embrace: The Abduction of First Nations Children and Restoration of Aboriginal Communities. Vancouver: Douglas \& McIntyre.

Gelles, R. J., \& Hargreaves, E. F. (1990). Maternal Employment and Violence Toward Children. In M. A. Straus \& R. J. Gelles (Eds.), Physical Violence in American Families: Risk Factors and Adaptation to Violence in 8,145 Families (pp. 507-526). New Brunswick, NJ: Transaction Publishers.

Gouvernement du Canada (2005). Les jeunes Canadiens: Qui sont-ils et que veulent-ils ? Service Canada. Site internet: http://www.youth. gc.ca/yoaux.jsp?\&lang $=$ fr \&geo $=402 \&$ flash $=1 \& \mathrm{t}$ a=1\&auxpageid $=846$.

Heilbron, C.L., \& Guttman, M.A. (2000). Traditional Healing Methods with First Nations Women in Group Counseling. Canadian Journal of Counseling/Revue Canadienne de Counseling, 34(1), 3-13.

Hosmer, D. W., \& Lemeshow, S. (1980). Goodnessof-fit Test for the Multiple Logistic Regression Model. Communications in Statistics - Theory 
and Methods, A9, 1043-1069.

Hudson, P., \& McKenzie, B. (1985). Child Welfare and Native People: The Extension of Colonialism. The Social Worker, 49, (2): 63-88.

Hudson, B. (1987). Manitoba's Indian Child Welfare Services. In J.S. Ismael \& R.J. Thomlison (Eds.), The balance: Perspectives on Social Services and Social Issues. Ottawa: Canadian Council on Social Development: 251-264.

Jiwani, Y. (2000). L'enquête sociale générale de 1999 sur la violence conjugale: une analyse. Center for Research on Violence Against Women and Children. Vancouver, Canada.

Kelleher, K., Chaffin, M., Hollenberg, J., \& Fischer, E. (1994). Alcohol and Drug Disorders Among Physically Abusive and Neglectful Parents in a Community-based Sample. American Journal of Public Health, 84 (10), 1586- 1590.

Kimelman, E.C. (1985). No Quiet Place. (Final Report). Review Committee on Indian and Métis Adoptions and Placements, Winnipeg, Manitoba: Department of Community Services.

Kunz, J.L., Milan, A., \& Schetagne, S. (2001). Inégalité d'accès : profil des différences entre les groupes ethnoculturels canadiens dans le domaine de l'emploi, du revenu et de l'éducation. Ottawa, Canadian Council on Social Development (Study prepared for the Canadian Race Relations Foundation).

LaDue, R.A. (1994). Coyote Returns: Twenty Sweats Does Not an Indian Expert Make. Women and Therapy, 15, 93-111.

LaFramboise, T.D., Trimble, J.E., \& Mohatt, G.V. (1990). Counseling Intervention and American Indian Tradition: An Integrative Approach. Counseling Psychologist, 18, 628-654.

Leung, S., \& Carter, J. (1983). Cross-cultural Study of Child Abuse Among Chinese, Native Indians, and Anglo-Canadian Children. Journal of Psychiatric Treatment \& Evaluation, 5, 37-47.

Lochhead, C., \& Shillington, R. (1996). Un profil statistique de la pauvreté urbaine. Ottawa: Le Conseil Canadien de Développement Social.

McSchane, D. (1988). An Analysis of Mental Health
Research with American Indian Youth. Journal of Adolescence, 11, 87-116.

Miller, J.R. (1996). Shingwauk's Vision: A History of Native Residential Schools. University of Toronto Press.

Ministère des Affaires Indiennes et du Nord Canada (2006). Analyse des conditions socioéconomiques, 1996 et 2001: indiens inscrits, indiens inscrits vivant dans une réserve et ensemble de la population canadienne. Catalogue no. R32163/2001F-PDF. Téléchargé à partir du site: http://www.ainc-inac.gc.ca.

Ministère de la Santé et des Services Sociaux (1998). Manuel de référence sur la protection de la jeunesse. Québec: Gouvernement du Québec.

Morin, A., \& Joncas, J. (2004). L'intervention thérapeutique auprès d'enfants amérindiens victimes d'agression sexuelle. Psychologie canadienne, 45 (1), 43-55.

O'keefe, M. (1995). Predictors of Child Abuse in Maritally Violent Families. Journal of Interpersonal Violence, 10, 3-25.

Peterson, L., Gable, S., \& Saldana, L. (1996). Treatment of Maternal Addiction to Prevent Child Abuse and Neglect. Addictive Behaviors, 21 (6), 789-801.

Réame, D.G., \& Maklem, P. (1994). Education for Subordination Redressing the Adverse Effects of Residential Schooling. Seven Generations: An Information Legacy of the Royal Commission on Aboriginal Peoples. CD Rom : Libraxas.

Santé Canada (2006). Stratégies relatives à l'évaluation des programmes de lutte contre l'abus des substances chez les autochtones: Examen de la question. Site internet: http://www.hc-sc.gc. ca/fnih-spni/pubs/ads/literary examen review/ index f.HTML.

Schetagne, S. (1999). La pauvreté dans les agglomérations urbaines du Québec. Conseil canadien de développement social.

Schumacher, J. A., Smith Slep, A. M., \& Heyman, R. E. (2001). Risk Factors for Child Neglect. Aggression and Violent Behavior, 6, 231-254.

Secrétariat aux affaires autochtones du Québec (2001). Les Amérindiens et les Inuits du Québec: Onze 
nations contemporaines. Québec: Gouvernement du Québec.

Secrétariat aux affaires autochtones du Québec (2005). Statistiques des populations autochtones du Québec. Québec: Gourvernement du Québec.

Sedlak, A.J. (1991). National Incidence and Prevalence of Child Abuse and Neglect: 1988. Rockville, MD: Westat.

Sedlak, A.J. (1997). Risk Factors for the Occurrence of Child Abuse and Neglect. Journal of Aggression, Maltreatment, \& Trauma, 1, 149-187.

Sedlak, A.J., \& Broadhurst, D.D. (1996). Third National Incidence Study of Child Abuse and Neglect. Washington, D.C.: National Center on Child Abuse and Neglect.

Solomon, G., Heisberger, J., \& Winer, J.L. (1981). Confidentiality Issues in Rural Community Mental Health. Journal of Rural Community Psychology, 2, 17-31.

Statistique Canada (2003). Enquête auprès des peuples autochtones de 2001-Premiers résultats: Bien-être de la population autochtone vivant hors-réserve. Catalogue no. 89-589-XIF

Statistique Canada (2003). Recensement de 2001, série " analyses ". Peuples autochtones du Canada : un profil démographique. Catalogue no. 96F0030XIF2001007.

Tiechroeb, R. (1997). Flowers on My Grave: How an Ojibway Boy's Death Helped Break the Silence on Child Abuse. Toronto: Harper Collins Publishers Ltd.

Topper, M.D. (1992). Multidimensional Therapy: A Case Study of a Navajo Adolescent with Multiple Problems. In L.A. Vargas \& J.D. Koss-Chioino (Éds.), Working with Culture: Psychoterapeutic Interventions with Ethnic Minority Children and Adolescents (pp .225- 245). San Francisco, CA : Jossey-Bass.

Tourigny, M., Mayer, M., Wright, J., Lavergne, C., Trocmé, N., Hélie, S., Bouchard, C., Chamberland, C., Cloutier, R., Jacob, M., Boucher, J., \& Larrivée, M.-C. (2002). Étude sur l'incidence et les caractéristiques des situations d'abus, denégligence, d'abandon et de troubles de comportement sérieux signalées à la direction de la protection de la jeunesse au Québec (EIQ). Montréal: Centre de Liaison sur
l'Intervention et la Prévention Psychosociales.

Trocmé, N., Knoke, D., \& Blackstock, C. (2004). Pathways to the Overrepresentation of Aboriginal Children in Canada's Child Welfare System. Social Service Review, 78 (4), 577-600.

Trocmé, N., MacLaurin, B., Fallon, B., Daciuk, J., Billingsley, D., Tourigny, M., Mayer, M., Wright, J., Barter, K., Burford, G., Hornick, J., Sullivan, R., \& McKenzie, B. (2001). Étude canadienne sur l'incidence des signalements de cas de violence et de négligence envers les enfants: rapport final. Ottawa, Ontario : Ministère de Travaux publics et Services gouvernementaux Canada.

Trocmé, N., McPhee, D., \& Kwam Tam, K. (1995). Child Abuse and Neglect in Ontario: Incidence and Characteristics. Child Welfare, 74 (3), 563- 586.

Trocmé, N., McPhee, D., Tam, K. K., \& Hay, T. (1994). Ontario Incidence Study of Reported Child Abuse and Neglect. Toronto, ON: Institute for the Prevention of Child Abuse.

Trudeau, A., \& Pellan, R. (1998). Définitions des termes et concepts utilisés dans la ventilation de la table des valeurs des articles 38 et 38,1 de la Loi sur la protection de la jeunesse. Montréal: Système clientèle jeunesse.

Vézina, A., \& Bradet, D. (1990). Inventaire concernant le bien-être de l'enfant en relation avec l'exercice des responsabilités parentales. Québec: MSSS et Centre de recherche sur les services communautaires.

Wekerle, C., Wall, A-M., Leung, E., \& Trocmé, N. (2004). Cumulative Stress and Substantiated Maltreatment: The Importance of Caregiver Vulnerability and Adult Partner Violence. Journal of Child Abuse \& Neglect. 31 (4), 427-443

Zuravin, S. J. (1987). Unplanned Pregnancies, Family Planning Problems, and Child Maltreatment. Family Relations, 36 (2), 135-139. 